\title{
Human Rights and Realities of Tribals' Lives in India: A Perfect Storm
}

\author{
Krishna Halavath \\ Department of Film Studies and visual communication, School of communication, English and Foreign \\ Languages University (EFLU), Hyderabad-500007, Andhra Pradesh State, India
}

\begin{abstract}
Tribal community in India has been most vulnerable community in the in equal, domination and exploitation ridden society. They are on the breadline of their socio-economic and political rights. Even after centuries, the unchanged condition of Tribal communities is leading in India. The violation of fundamental human rights and the state brutality has been perpetrated on them, particularly on tribal women. Tribal communities have faced isolation and social discrimination like that of Dalits from the mainstream society. Understanding of current Tribal societies need a basic respect to the historical processes, which have determined the course of consecutive changes in ideological, political, economic and socio cultural life of the Tribal communities. The Indian democratic state accords several statutes in the constitution where the rights of Tribal communities are protected and social justice is determined for. However, the democratic experiment has not been successful in this respect. Therefore, there is a surge of Tribal movements in the country for their rights. All tribal people of India have a thing in common- they all share a history of injustice. The present paper explores within the larger framework of human rights in general and how tribal rights violated in particular, in India.
\end{abstract}

Key words: Constitution of India, Discrimination, Human Rights, Indian Society, Social Justice and Tribal Communities

\subsection{Tribal People: Indian Context}

\section{Introduction}

The Tribal people in India have a long history even before the arrival of the colonial government. The Tribal societies that existed prior to the colonial intervention had their own rights and duties within their autonomous sovereign framework. Apart from the encounter of the Tribals with the various civilizations, there was also the influence of the foreign missionaries in the past and of the dominant society through the fundamentalist forces in the recent past (Minz, 1993) There is a little doubt that Tribal communities continue to be the most marginalized group in India. Social indicators of developments tell that Tribal people have life expectancies that are decades shorter than the non-tribals are. Any other social indicator, be it standards of health facilities education opportunities and attainment, level of employment or standard of housing, sees Tribal communities enjoying fewer opportunities, and suffering greater burdens, than the rest of the Indian population.

\section{Rights of Tribal Communities are at Stake}

Human rights are the birthrights of every human being and they form an integral part of the socio-cultural fabric of humanity all over the world. However, they are vulnerable to abuse and violation. Human rights can be understood as abstract norms and values protected in laws, constitutions, and international conventions. At the same time, human rights are cultural concepts that are slowly evolving in response to social change or contestation (Nair Ravi, 2006). The paper explores how human rights have become applicable to the realities of Tribal lives, and how we can build on the international conventions and agreements that have accomplished this task to understand the dimensions of Tribals' human rights in the Indian society. Tribals' human rights provide fundamental insights into the causes, manifestations and consequences of human rights violations experienced by Tribal communities.

In India, the last quarter of the 20th century has been a witness to the growing recognition of the place and relevance of human rights due to pressure from various collective movements. It is obvious that this concern in human rights is rooted in the denial of life and liberty that was a pervasive aspect of the emergency (197577). The mass arrests of the leaders of the opposition and the targeted apprehension of those who could present a challenge to an authoritarian state are some of the dominant images that have survived. The civil liberties movement was a product of the crisis. Preventing subjective detention, imprisonment, the use of the judicial process non-transparently and custodial violence were on the agenda of the civil liberties movement. For past 
two decades, movements of peasants, tribals, Dalits, women, students and working class movements have highlighted human rights concerns (Shah, 2004)

Thus, human rights have become prominent on the national and international agenda. Coinciding with the United Nation Declaration, the Indian Constitution also replicates that, the State will not distinguish against any citizen on grounds of birth, place, ethnic, religion, caste and agreed that the promotion and protection of all human rights is a legitimate concern of the State. These include basic survival rights to health care, shelter, food and social security; the right to work; the right to education; and the right to participate in the cultural life of one's society. However, there is a huge gap between the ideal of the human rights laws and the reality of continuing gross human rights violations of Tribal communities in India (Poutler, 1998)

\section{Land Alienation to non-tribals}

The constitutional safeguards as provided in the $5^{\text {th }}$ Schedule of the Constitution of India and various other State level laws which among others prohibit transfer of the lands of the Tribal communities have failed to prevent widespread land alienation of the Tribal people. The core cause of the land alienation has been the Land Acquisition Act- 1894 under which the government can exercise its sovereign power to take away any land in the name of "public purposes".

The non-tribals have also illegally occupied hundreds acres of land belonging to Tribal communities by force in Andhra Pradesh, allurement and acquiring Tribal lands by marrying Tribal women. There is ample of evidences that a majority of these non-tribals are from coastal Andhra upper caste and ruling classes. Many scholars who worked on Tribal issues have raised these issues very often. Even Girglani, J.M in his report on 'Tribal Land issues in Telangana Area' submitted to the Government in 2005 says that Telangana have been losing land to non-tribals since long back. The Gonds of Adilabad in the 1930s lost land to Marathis and during1940s to Hindu and Muslim settlers invited by the Nizam from neighboring districts (Revathi, 2013). The famous Regulation of 1/1970, Scheduled areas in Telangana saw an arrival of non- tribal population, which in due course of time has passed into the hands of Telugu non-tribals mostly from four central coastal Andhra districts. The onslaught of non-tribals from costal districts over scheduled areas in Telangana continued unabated. According to estimates as much as 1.5 lakhs acres of fertile lands along Godavari River banks of Warangal and Khammam have passed into hands of dominant caste people such as Kamma, Rajulu, Reddy and Kapu landlords and cultivators belonging to the coastal area due to ineffective implementation of the Land Transfer Regulation Acts (LTR). In similar lines with Kerala, Andhra Pradesh Land Transfer Regulation-1959 was amended in 1970, in an attempt to accommodate the interest of non-tribals as a result Khammam district has become a victim to most atrocious non-tribals penetration from coastal areas.

\section{Failure to ensure Forest Rights}

After the emergence of private property and the emergence of modern nation states, as Tribal communities have no legal rights over the lands they have been living on and cultivating for generations, it became easy for the non-tribals to acquire the land of Tribal people. Often, the law declares these unregistered lands as reserved or protected forests, or sanctuaries and national parks. The access of Tribal communities to forest produce or to the grazing of cattle is rendered illegal, they are threatened and penalised for entering into the forest. A large number of these people belong to the Tribal communities. They live every day under the unpredictable threat of being evicted from their homes; the only legal protection they have is the due process of law. Over the years, when these people have protested against oppression by the forest department or raised their voices to demand legal rights, the State has used force to suppress them - to the extent of denying them the right to life.

The National Forest Policy of 1988 recognizes symbiotic relationship between forest and Tribal communities yet; the Tribal people have been systematically victimized under the Forest Act of 1927. When the Forest Conservation Act of 1980 came into implementation, thousands of acres of land of Tribal communities were encroached over night. In 2006, the government of India brought the Scheduled Tribes and Other Traditional Forest Dwellers (Recognition of Forest Rights) Act. The Act is aimed at undoing the age-old injustice done to Tribal communities by restoring and recognizing their pre-existing rights (Tipper, 2014). The recognition and restoration has been, however passing through rough weather in respect of its implementation. The Government of India till today has failed to notify the Rules of Procedures of the Forest Rights Act of 2006. In the meanwhile, Tribals continue to be prosecuted for accessing minor forest produce. There were 2,57,226 forest cases pending against 1,62,692 Tribal communities between 1955 and 30 June 2006 under different Sections of the Forest Act of 1927.

\section{Development policies became Disadvantage to Tribal Communities}

Tribal people who constituted $8.6 \%$ of the total population of India as per 2011 census also constituted $55.1 \%$ of the total development project-induced displaced persons up to 2010 on account of mega 
developmental projects like industries, mining, dams, wild life sanctuaries, parks and conservation of nature, etc. Development projects have become more problematic particularly in Andhra Pradesh during the last few decades. In this context take the Polavaram dam, which is to be built across the Godavari River which will displace around 400,000 people in the three states; Andhra Pradesh, Chhattisgarh and Orissa. Of them at least 150,000 are Tribals (the submergence area includes 170 habitations of Koya and Kondareddy ) particularly vulnerable Tribal groups dearly in terms of livelihood and preservation of distinctive cultural heritage are in shock and the rest mostly Dalits dependent on minor forest produce for their livelihood. Displacement not only disrupts the lives of the individuals and families concerned, but also their entire communities and societies. In many cases, due to displacement, socio-economic systems and community structures breaks down (Huhua, 2009). As a result, Tribal communities are at the lowest point in every socio-economic indicator. Moreover, they are seldom rehabilitated. As India's active economy involves further resources, Tribal communities face more displacement. In the last three years, the National Policy on Resettlement and Rehabilitation for Project Affected Families of 2004 was amended twice - in 2006 and 2007, but failed to address the problems of displaced people. Tribal communities must resist for their right and democratic conscious people should support them in this respect.

\section{Culture and Language Rights of Tribal communities}

Tribal communities have been unable to safeguard and promote their language and culture; even though Article 19(5) of the constitution states that a cultural or linguist minority has the right to conserve its language and culture. This means that Triblas as individual and groups have right to use their own language, to practice their own culture, to study their own history, tradition and heritage etc.( Xaxa, 1999) The state cannot, by law, impose upon them any other culture or language. While the state may not have enforced any language or culture on them, neither has it taken any positive steps worth the name towards meeting this provision of the constitution. Rather, the steps taken are far from being in consonance with the provisions laid down in the constitution. The posture that they adopted has invariably been in the direction of assimilation into the language and culture of the major community, rather than protection and promotion of the distinct language and culture of the Tribal communities. Schooling extended to Tribal communities for example, has invariably been made in the language of the dominant regional community of the respective states or in English. The result is that Tribal communities are increasingly losing knowledge of their own language and culture. Indeed the promotion of language and culture has been left to Tribal communities themselves. Yet, because of lack of control over human, organizational and financial resources, the Tribal communities have not been able to take effective measures in this direction. Only where such support has been made available in some form or the other the Tribal communities have been able to protect and safeguard their culture.

\section{Violation of PESA Act in India}

To reinforce the constitutional provisions for protection of the Tribal communities, this important Panchayat (Extension to the Scheduled Areas) PESA Act1996, has been enacted in recent years. The act empowers the scheduled Tribes to safeguard and preserve the traditions and customs of the people, their cultural identity, community resources and customary mode of dispute resolution through the Gram Saba. Interestingly, the provisions of the Panchayat Act hardly find its due place in latter and spirit. However, there are extensive violations of the PESA Act, 1996, in mining and land acquisition in the Scheduled Areas of Andhra Pradesh, Chhattisgarh, Jharkhand and Orissa. Clause 4.e.(1) of the Panchayats (Extension to the Scheduled Areas) Act, 1996, provides that "every GramSabha shall approve the plans, programmes and projects for social and economic development before such plans, programmes and projects are taken up for implementation". Again, clause 4. (i) says that "the Gram Sabha or the Panchayat at the appropriate level shall be consulted before making the acquisition of land in the Scheduled Areas for development projects. And before resettling or rehabilitating persons affected by such projects in the Scheduled Areas, the actual planning and implementation of the projects in the Scheduled Areas shall be coordinated at the State level" (Memorandum, 2010). Despite the above provisions for the rights of the Tribal communities, no necessary initiations are taken up during any developmental project to take the opinion and consent of the GramSabha, which constitutes people's opinions. The recommendations of Gram Sabha are not made mandatory prior to granting prospecting license or mining lease in many cases. For example in the case of Polavaram a multipurpose project, Gram Sabhas are not conducted in villages and peoples consent has not been taken. This process is neither followed in Andhra Pradesh nor in the neighboring states like Orissa and Chattisgarh. Even though this project did not get environmental clearance, construction of project has been initiated.

The Constitution entrusts the Governor the task of ensuring 'peace and good governance' in Schedule Five Areas, with absolute powers over the state government towards this end. Governors were also required to submit an annual report to the Parliament, which was meant to be an independent assessment on administration in Schedule Five Areas. However, since the enactment of PESA, Governors have slowly but surely been 
neglecting their duties towards the law, and towards the welfare of the Tribal communities. Even The government of India has also failed to materialize Tribal sub plan in the country.

\section{Conclusion}

Violation of human rights creates many economic and emotional problems. It affects the nature and welfare of human beings, and creates many disorders. It is possible to imagine the life chances of Tribal communities improving through the implementation of practical measures along with considering the rights accorded. However, silence on rights will always carry with it the danger of a return to paternalism and the treatment of an identifiable group of people as a 'problem' worthy of charity, not as a group of human beings to whom society has responsibilities and duties. The constitutional guarantee, which governs and protects the rights and sovereignty of Tribal communities, need an immediate implementation. Otherwise, this would lead to a disappearance of the various Tribal communities from the human picture. The Tribal communities' sovereignty is at stake by the intervention of non-tribes in their area. Therefore, there is an immediate need to constitute Tribal autonomy councils so that the Tribal communities themselves can look after the rules, implementation and development of the localities.

\section{References}

[1]. Minz, N. (1993).Cultural Identity of Tribals in India. Social Action, Vol. 43, Jan-March. Pp 32- 40.

[2]. Nair, R. (2006). Human rights in India: Historical, social and political perspectives. New Delhi: Oxford University Press.

[3]. Poulter, S. (1998). Ethnicity, Law and Human Rights. The English Experience, Oxford Clarendon Press

[4]. Shah, G. (2004). Social movements in India: A review of literature. New Delhi: Sage Publications

[5]. Revathi, E. (2013, August 27). Adivasis and Telangana the Hans India .P 4

[6]. Thipper, B. (2014, Feb17). Right over forest land for tribals in the offing, The Indian Express, P. 6

[7]. Huhua,Cao. (2009). Ethnic Minorities and Regional Development in Asia. Amsterdam University Press

[8]. Xaxa, Virginius. (1999). Tribes as Indigenous people Economic and political Weekly, 34No.51 December 18-28, Pp. 358.

[9]. Sharma, B. D. (2001). Tribal Affairs in India: The Crucial Transition. New Delhi: Sahyog Pushtak Kuteer.

[10]. Sharma B.D (2010) 'Report of the sub-committee appointed by the Ministry of Panchayati Raj to draft Model Guidelines to vest Gram Sabhas with powers as envisaged in PESA'

[11]. Aiyar Mani, S. (2002) 'Panchayati Raj: The Way Forward', Economic and Political Weekly, August 2002

[12]. Baxi, Upendra. (2002). The future of human rights. New Delhi: Oxford University Press

[13]. Menon, P. S. K. \& Sinha, Bakshi D. (2003). Panchayati Raj inScheduled Areas. New Delhi: Institute of Social Sciences.

[14]. Ministry of Tribal Affairs, Government of India Retrieved from http:// tribal.nic.in/ visited on (March $\left.3^{\text {rd }} 2014\right)$

[15]. Sachar, R. (2009). Human rights-Prospects \& challenges New Delhi: Gyan Publishing House.

[16]. Singh, M. (2009), Address at the Chief Ministers' Conference on Implementation of the Forest Rights Act, November 2009

[17]. Suresh, H. (2003). Fundamental rights as human rights. Mumbai: Sabrang Communications and Publishing Pvt. Ltd. 